\title{
CONCENTRATION OF SERUM PROTEIN-BOUND IODINE IN NORMAL MEN 1, 2
}

\author{
BY ROBERT G. TUCKER ${ }^{3}$ AND ANCEL KEYS \\ (From the Laboratory of Physiological Hygiene, University of Minnesota, Minneapolis, Minn.)
}

(Submitted for publication January 17, 1951; accepted June 4, 1951)

During recent years the determination of the protein-bound iodine (PBI) in the serum or plasma has been used with increasing frequency as a diagnostic aid. Various limits have been suggested for the serum PBI concentration in euthyroidism. The range most frequently recorded in the literature is from 4 to 8 gamma per cent of PBI. These values are not fiducial expressions of full statistical analyses of adequate numbers of persons; they are based on observations made by several groups of workers on limited numbers of persons judged to be euthyroid but otherwise not fully characterized (Table I). The present paper

\section{TABLE I}

Literature values for normal serum $P B I$ in man All values in micrograms per $100 \mathrm{ml}$. of serum.

\begin{tabular}{l|c|c|c|c}
\hline \hline \multicolumn{1}{c|}{ Authors } & $\mathrm{N}$ & Mean & S. D. & Range \\
\hline Salter, Bassett, and Sapping- & 21 & $5.7^{*}$ & $1.0^{*}$ & $4.0-8.0$ \\
$\quad$ ton (1) & 11 & 7.0 & & $6.0-8.4$ \\
Talbot and associates (2) & 34 & 5.9 & 1.3 & $4.0-9.3$ \\
Perry and Cosgrove (3) & & 4.8 & & $4.0-6.0$ \\
Conner and associates (4) & 83 & $5.3 \dagger$ & $1.0 \dagger$ & $3.8-8.5$ \\
Kydd, Man, and Peters (5) & 83 & 5.6 & $0.9 \dagger$ & $4.0-8.5$ \\
Starr and associates (6) & 100 & & & \\
\hline
\end{tabular}

* Calculated from Figure 2.

† Calculated from Figure 1.

reports the results, including statistical analysis, from 402 young and middle-aged men who are clinically "normal" in all respects and who represent active urban "white collar" workers in the upper Midwest.

1 Abridgement of material contained in a thesis submitted by Robert G. Tucker to the Faculty of the Graduate School of the University of Minnesota in partial fulfillment of the requirements for the degree of Doctor of Philosophy.

2 The subjects studied in the Laboratory of Physiological Hygiene were available in connection with a longrange research project sponsored by the U. S. Public Health Service on the recommendation of the Cardiovascular Study Section.

${ }^{3}$ Present adress: Radioisotope Unit, Veterans Administration Hospital, Nashville, Tenn.

\section{METHODS}

Serum PBI concentration was determined by the method of Barker (7) modified as follows: (1) In the distillation of iodine, sodium arsenite solution was substituted for sodium sulfite solution as the alkaline reducing substance in the trap. This modification was suggested by Dr. Barker in a personal communication. To $20 \mathrm{ml}$. of $5 \mathrm{~N} \mathrm{NaOH}, 1.5$ grams of $\mathrm{As}_{2} \mathrm{O}_{3}$ are added, and the resulting solution is diluted with distilled water to $100 \mathrm{ml}$. One-half $\mathrm{ml}$. of this solution is used in the trap in place of $0.5 \mathrm{ml}$. of sodium sulfite solution. Aeration is no longer necessary. The cooled distillate and washings can be diluted to $25 \mathrm{ml}$., mixed, and the iodide content determined directly by cerate colorimetry. (2) Phosphorous acid was found to be the reagent which was most apt to cause difficulty. An aqueous 50 per cent solution of phosphorous acid (Fisher Scientific Company) was filtered through an asbestos mat and boiled with $2 \mathrm{ml}$. of Superoxol for one hour at approximately constant volume. This effectively removed traces of iodine and organic matter. (3) Blood serum was used for analysis rather than blood plasma. (4) Blank values were determined from completely inorganic samples.

The PBI method was studied and standardized with great care before any of the material reported here was analyzed. Known amounts of iodine as sodium iodide were added to serum in repeated recovery experiments which demonstrated apparent complete recovery of iodine with an occasional high value. For example, in the last series of such tests, $0.1 \gamma$ of iodine was added to each of four aliquots of pooled serum which had on repeated analysis an average of $4.75 \gamma$ of PBI per $100 \mathrm{ml}$.; the apparent recoveries of added iodine were 100,100,100 and 130 per cent. Three samples of serum were exchanged with the Department of Biochemistry of the Mayo Clinic with the results shown in Table II; both of the laboratories used the same analytical procedure.

Finally, the reproducibility of single measurements was checked. In a series of 12 aliquots, with a mean value

TABLE II

Collaborative check samples

Values for micrograms of iodine per $100 \mathrm{ml}$. of serum.

\begin{tabular}{c|c|c|c}
\hline \hline \multicolumn{1}{c|}{ Sample } & Test & Mayo Clinic & U. of Minn. \\
\cline { 2 - 2 } Human serum & Total I & 3.6 & 4.3 \\
Human serum & PBI & 5.5 & 5.6 \\
Human serum (exoph- & PBI & 16.2 & 16.4 \\
thalmic goiter) & & & \\
\hline
\end{tabular}


of $4.77 \gamma$ per $100 \mathrm{ml}$. of serum, the standard deviation was \pm 0.60 . This suggests that in nine out of 10 cases a single measurement of PBI will be within $\pm 1.0 \gamma$ per $100 \mathrm{ml}$. of the true (mean) value. It seems possible, however, that the error of measurement is not absolute but is related to the concentration of PBI in the sample. If the error were strictly proportional to the total concentration, we might estimate that in nine out of 10 cases a single PBI measurement will be within \pm 21 per cent of the true (mean) value of the serum examined. From trials with high PBI sera, however, this appears to be an overestimate of the error and we conclude that for ordinary clinical work the reliability of a single measurement can be taken to be within $1 \gamma$ per cent.

The serum total cholesterol determination was made by application of the Liebermann-Burchard reaction to a Bloor extract. This procedure as used here at constant temperature, with cholesterol standards for every batch, closely checks with the Schoenheimer-Sperry digitonin method which was, in fact, applied in parallel from time to time (8). The basal oxygen consumption was determined with the Sanborn apparatus by the standard technique used by Boothby, Berkson, and Dunn (9). The normal weight for each subject was estimated according to his height and age by referring to the tables published from the Medico-Actuarial Investigations of 1912; these are sometimes called Davenport's tables and are, in essence, the tables almost universally used in the United States. The per cent of normal weight was calculated according to the formula : $\frac{\text { actual weight }}{\text { normal weight }} \times 100=$ per cent of normal weight.

\section{MATERIAL}

The normal men used in the present work have been studied rather intensively in other respects $(8,10)$. They are of northern European ancestry (chiefly descended from stock from the British Isles) and are actively and successfully engaged in non-manual pursuits in the metropolitan communities of Minneapolis and St. Paul. Included here were 130 younger men (18 to 25 years of age) students in the University of Minnesota and 272 middle-aged (45 to 56 years of age) business and professional men. Each man was subjected to a physical examination by a competent internist and was carefully questioned as to medical history, fatigue, "nervousness," etc. The absence of complaints, tremor or abnormal heart rate and the presence of normal basal metabolic rate, all contributed to the considered judgment that these men were euthyroid. This judgment was sustained by repeated examinations in three successive years. All of the men came to the laboratory in the morning without breakfast, and all data refer essentially to the basal state.

\section{RESULTS}

The descriptive statistics for the sample of normal men are given in Table III. The sample of normal serum $\mathrm{PBI}$ value did not form a normal frequency distribution curve (Figure 1). By calculation of the beta coefficients the distribution was found to be significantly skewed and peaked so that the standard deviation is an inappropriate

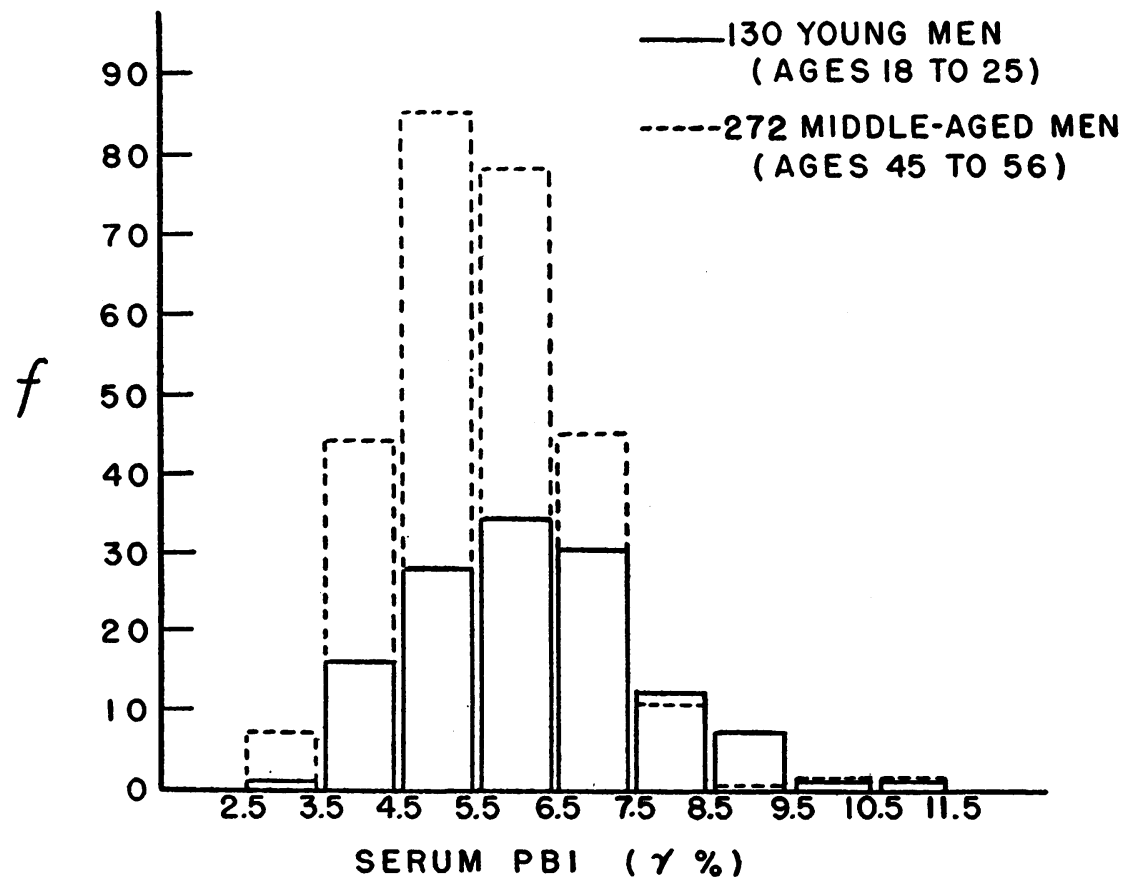

Fig. 1. Frequency Distribution of Serum PBi Values in Normal Men 
TABLE III

Descriptive statistics for the sample of normal men

\begin{tabular}{|c|c|c|c|c|}
\hline & Statistic & PBI & BMR & $\begin{array}{l}\text { Cho- } \\
\text { lesterol }\end{array}$ \\
\hline $\begin{array}{l}\text { Young men } \\
\text { (18-25 years; } N=130)\end{array}$ & $\begin{array}{l}\text { Mean } \\
\text { S. D. } \\
\text { Range }\end{array}$ & $\begin{array}{c}\gamma \% \\
6.24 \\
1.46 \\
3.1-11.0\end{array}$ & $\begin{array}{c}m l . O z / m .2 \\
128.2 \\
11.7 \\
78.8-171.6\end{array}$ & $\begin{array}{c}m g . \% \\
188.6 \\
36.3 \\
106-285\end{array}$ \\
\hline $\begin{array}{l}\text { Middle-aged men } \\
(45-56 \text { years; } N=272)\end{array}$ & $\begin{array}{l}\text { Mean } \\
\text { S. D. } \\
\text { Range }\end{array}$ & $\begin{array}{c}5.63 \\
1.21 \\
2.6-11.1\end{array}$ & $\begin{array}{c}116.3 \\
11.6 \\
77.3-161.6\end{array}$ & $\begin{array}{c}261.3 \\
45.7 \\
157-421\end{array}$ \\
\hline $\begin{array}{l}\text { Combined groups } \\
(\mathrm{N}=402)\end{array}$ & $\begin{array}{l}\text { Mean } \\
\text { S. D. } \\
\text { Range }\end{array}$ & $\begin{array}{c}5.83 \\
1.32 \\
2.6-11.1\end{array}$ & $\begin{array}{c}120.2 \\
12.9 \\
77.3-171.6\end{array}$ & $\begin{array}{c}237.8 \\
54.8 \\
106-421\end{array}$ \\
\hline
\end{tabular}

measure of dispersion. Therefore standards for the serum PBI concentration were established for the population from which the sample was drawn by computing the 1.0, 5.0, 95.0 and 99.0 percentile values. These standards are listed in Table IV which provides, in each group, the expected ranges, as upper and lower limits, for 95 and 99 per cent of the normal population. For example, in normal young men 95 per cent of observed values are expected to be greater than 3.98 gamma per cent of PBI, and 99 per cent greater than 3.58 gamma per cent; at the other extreme 95 per cent of the observed normal values are expected to be less than 8.70 gamma per cent of $\mathrm{PBI}$, and 99 per cent less than 9.82 gamma per cent.

The relationships between the serum PBI concentration and several other characteristics of these men were studied by an analysis of variance. The independent variables considered were: (1) age; (2) the basal metabolism expressed as ml. of oxygen consumption per square meter of body surface per minute; (3) the serum total cholesterol concentration; (4) the per cent of normal body weight. The relationships between these characteristics and the PBI were studied for the sample as a whole

TABLE IV

Range of serum PBI concentration for 95 and for 99 per cent of the population of normal men

Values for micrograms of iodine per $100 \mathrm{ml}$. of serum

\begin{tabular}{l|c|c|c|c}
\hline \hline \multicolumn{1}{c|}{ Group } & $\mathrm{N}$ & Level & $\begin{array}{c}\text { Lower } \\
\text { limit }\end{array}$ & $\begin{array}{c}\text { Upper } \\
\text { limit }\end{array}$ \\
\hline Young men & 130 & $95 \%$ & 3.98 & 8.70 \\
$\quad(18-25$ years) & & $99 \%$ & 3.58 & 9.82 \\
Middle-aged men & 272 & $95 \%$ & 3.87 & 7.52 \\
(45-56 years) & & $99 \%$ & 3.32 & 8.51 \\
Combined groups & 402 & $95 \%$ & 3.90 & 8.15 \\
& & $99 \%$ & 3.35 & 9.55 \\
\hline
\end{tabular}

and for the group of young men and the group of middle-aged men.

No significant correlation was observed between age and the serum PBI within the limited ranges of either the young group or the middle-aged group. However, the mean for the young group of normal men was significantly higher (above the 1 per cent level), as shown by calculating Snedecor's F ratio, in serum $\mathrm{PBI}$ than the mean for the middleaged group.

A slight but significant positive correlation was demonstrated for the combined groups between the serum PBI and the basal metabolic rate $(r=$ $+0.113)$. This was accepted with reservations, because it was shown that the relation approaches curvilinearity. No correlation was observed between the serum PBI and the basal metabolic rate within the young group or within the middle-aged group of men. Therefore, in normal men variations in the basal oxygen consumption are due largely to factors other than the circulating PBI.

In the middle-aged group of normal men a slight but significant, positive, and linear correlation $(r=+0.163)$ was observed between the serum $\mathrm{PBI}$ and the serum cholesterol concentration; no such relation was found in the group of normal young men. For the gross sample of normal men a curvilinear relationship was demonstrated between the serum PBI and the serum cholesterol.

No relationship was demonstrated between the serum PBI concentration and the per cent of normal body weight in normal young men, in normal middle-aged men, or in the gross sample.

\section{DISCUSSION}

The serum PBI data for the sample of men reported here constitute the largest sample of normal men which has been studied with modern analytical techniques. The sample is by no means random. The subjects were selected with respect to sex, race, age, economic status, geographic habitat and physical condition. Nevertheless, the frequency distribution of the 402 serum PBI values is remarkably similar to the sample described by Kydd, Man, and Peters (5). Our mean value of 5.8 gamma per cent of $\mathrm{PBI}$ is significantly higher than the mean of 5.3 gamma per cent calculated from Kydd's data. However, by using a Chi 
square test for goodness of fit, and by making the two distributions comparable by expressing them in units of absolute deviation from their respective absolute means, the obtained Chi square value of 1.83 associated with seven degrees of freedom indicates that a discrepancy as large as that observed could occur through chance alone 97 times out of 100 . From this very close relationship we infer that there is no statistical difference between the shape of the two frequency distribution curves, and that the distribution of PBI values in the common population from which they were drawn is non-Gaussian. The two samples would be identical in all respects except for the apparent presence of a systematic analytical difference which could be explained, possibly, as a result of slight differences in method or of a difference in the age composition of the samples.

With respect to age our results are in agreement with those of Kountz, Chieffi, and Kirk (11) who reported, "a gradual decrease in the organic serum iodine concentration ... with advancing years." The resemblance to the basal metabolic rate trend with age may be noted, but the age trend in serum PBI concentration is considerably less pronounced. The lack of correlation between the serum PBI concentration and the basal oxygen consumption merely emphasizes that the one is not closely dependent on the other in this normal range.

Our data on cholesterol are somewhat difficult to interpret. However, we are in substantial agreement with Peters and Man (12) who found no important relationship between the precipitable iodine and the cholesterol in the serum in euthyroidism. There is no denying the fact that a very slight relation does exist between the serum PBI and the cholesterol level in the middle-aged men, however.

Williams (13) "concluded that an alteration of thyroid function does not have much etiologic significance in obesity." This view is confirmed by the present study. In 33 obese men of the Minnesota study (those whose body weight exceeded 126 per cent of the normal mean standard weight), only three had serum PBI values of less than 4.0 gamma per cent. This suggests that in otherwise normal men obesity is due, for the greater part, to factors other than the activity of the thyroid gland.

\section{SUMMARY}

From the study of the protein-bound iodine (PBI) in the serum of 402 normal men in Minnesota, the following conclusions are drawn:

1. The frequency distribution of serum PBI values in normal men is significantly peaked and skewed.

2. Standards for serum PBI values have been established for the 95 and for 99 per cent of the population for which these normal men represent a sample.

3. Normal middle-aged men ( 45 to 56 years of age) are significantly lower in serum PBI than normal young men (18 to 25 years of age).

4. In normal men a small but significant, positive correlation $(r=+0.113)$ exists between the serum PBI and the basal oxygen consumption. Differences in the basal metabolic rate of normal men are dependent largely on factors other than the circulating PBI.

5. In normal middle-aged men ( 45 to 56 years of age) a positive, linear correlation $(r=+0.163)$ exists between the serum PBI and the serum total cholesterol concentration; no such relation obtains in normal young men (18 to 25 years of age). For both young and middle-aged normal men studied collectively, a curvilinear relation exists between the serum PBI and the serum cholesterol.

6. In normal young men and in normal middleaged men, no relationship exists between the serum $\mathrm{PBI}$ and the relative obesity of the individual.

\section{REFERENCES}

1. Salter, W. T., Bassett, A. M., and Sappington, T. S., Protein-bound iodine in blood. VI. Its relation to thyroid function in 100 clinical cases. Am. J. M. Sc., 1941, $202,527$.

2. Talbot, N. B., Butler, A. M., Saltzman, A. H., and Rodriguez, P. M., The colorimetric estimation of protein-bound serum iodine. J. Biol. Chem., 1944, 153, 479.

3. Perry, W. F., and Cosgrove, J. B. R., Protein-bound plasma iodine as an aid in the diagnosis of thyroid disease. Canad. M. A. J., 1949, 60, 602.

4. Conner, A. C., Swenson, R. E., Park, C. W., Gangloff, E. C., Lieberman, R., and Curtis, G. M., The determination of the blood iodine. Surgery, 1949, 25, 510 .

5. Kydd, D. M., Man, E. B., and Peters, J. P., Concentration of precipitable iodine in the serum. $\mathrm{J}$. Clin. Invest., 1950, 29, 1033. 
6. Starr, P., Petit, D. W., Chaney, A. L., Rollman, H., Aiken, J. B., Jamieson, B., and Kling, I., Clinical experience with the blood protein-bound iodine determination as a routine procedure. J. Clin. Endocrinol., 1950, 10, 1237.

7. Barker, S. B., Determination of protein-bound iodine. J. Biol. Chem., 1948, 173, 715.

8. Keys, A., Mickelsen, O., Miller, E. v.O., Hayes, E. R., and Todd, R. L., The concentration of cholesterol in the blood serum of normal man and its relation to age. J. Clin. Invest., 1950, 29, 1347.

9. Boothby, W. M., Berkson, J., and Dunn, H. L., Studies of the energy of metabolism of normal individuals : a standard for basal metabolism, with a nomogram for clinical application. Am. J. Physiol., 1936, 116, 468.

10. Keys, A., Mode of life and the development of heart disease: research for a preventive hygiene. Chicago Heart Assoc. Bull., 1948, 26, 3.

11. Kountz, W. B., Chieffi, M., and Kirk, E., Serum protein-bound iodine and age. J. Gerontol., 1949, 4, 132.

12. Peters, J. P., and Man, E. B., The significance of serum cholesterol in thyroid disease. J. Clin. Invest., 1950, 29, 1.

13. Williams, R. H., Relation of obesity to the function of the thyroid gland, especially as indicated by the protein-bound iodine concentration in the plasma. J. Clin. Endocrinol., 1948, 8, 257. 